\title{
Genesis and evolution of lithium pegmatites - African examples
}

\author{
K. M. GoOdenOUGH ${ }^{1, *}$, R. A. SHAW ${ }^{2,}$ P. NEX ${ }^{3}$ AND
}

\section{J. KINNAIRD ${ }^{3}$}

${ }^{1}$ British Geological Survey, Research Avenue South, Edinburgh EH14 4AP, UK (*correspondence: kmgo@bgs.ac.uk)

${ }^{2}$ British Geological Survey, Keyworth, Nottingham, NG12 $5 \mathrm{GG}, \mathrm{UK}$

${ }^{3}$ School of Geosciences, University of the Witwatersrand, South Africa

Global commitments to decarbonisation of energy and transport, including a switch to electric vehicles, have led to forecasts of increased demand for the raw materials required in batteries (World Bank, 2017). One such raw material is lithium, which is currently mined from two distinct types of sources: evaporative brines, largely in South America; and rare-metal pegmatites. Lithium-enriched rare-metal pegmatites occur worldwide, with the most significant mines in Australia and Zimbabwe. These pegmatites may also show enrichment in other valuable commodities such as tin, tantalum, caesium and beryllium. However, debate continues over the processes of rare metal enrichment in these pegmatites, including magma sources, emplacement mechanisms, magmatic-hydrothermal processes, and controls on which minerals crystallise. The latter point is particularly important for lithium, since the ore mineralogy and chemistry has a significant impact on end-use.

To investigate these processes, we are using African pegmatites as case studies, including examples from Zimbabwe, Namibia, Ghana and Mali. These pegmatites show variable and often patchy zonation. Marginal zones are dominated by qtz + feldspar + mica \pm tourmaline, and generally lack rare metals. In the cores of the pegmatites, lithium minerals (most commonly petalite and/or spodumene) and in some cases caesium minerals (pollucite) form at a relatively early stage. Subsequent hydrothermal alteration leads to extensive albitisation and greisenisation. Tin and tantalum minerals may be associated with this late-stage mineralisation, whilst original lithium minerals are altered and broken down into a range of lithium-bearing micas, zeolites and phosphates. Low-temperature alteration and weathering may also have an impact on lithium budgets within the system. An understanding of ore mineralogy and paragenesis in rare-metal pegmatites is thus essential to underpin exploration and development. 